\title{
Analisis Megaskopis dan Sebaran Sedimen di Perairan Serdang Bedagai Sumatera Utara
}

Nur Ella Handayani ${ }^{*}$, Yusuf Adam Priohandono ${ }^{b}$

aProgram Studi Geofisika FMIPA Universitas Tanjungpura

${ }^{b}$ Pusat penelitian dan pengembangan geologi laut

*Email : Nurella792@gmail.com

\begin{abstract}
Abstrak
Telah dilakukan penelitian tentang identifikasi jenis dan sebaran sedimen di dasar Perairan Serdang Bedagai Sumatera Utara berdasarkan deskripsi megaskopis dan analisis besar butir. Pengolahan data dilakukan menggunakan metode ayakan (granulometry) dengan saringan berukuran -2 hingga 4 phi dan dianalisis menggunakan analisis megaskopis dan parameter statistik sedimen. Hasil penelitian menunjukkan bahwa perairan Serdang Bedagai memiliki nilai terpilah buruk pada pemilahan, dominan mesokurtic pada kurtosis, dan dominan simetris pada nilai skewness. Berdasarkan hasil analisis megaskopis diketahui bahwa sedimen di perairan Serdang Bedagai didominasi oleh pasir warna coklat gelap dan coklat terang dengan bentuk butir membundar, besar butir pasir sedang, dan struktur sedimen yang didominasi oleh homogen. Berdasarkan nomenklatur sedimen diketahui pula bahwa dasar perairan Serdang Bedagai ditutupi oleh pasir, pasir lanauan, lanau pasiran, lanau, dan pasir sedikit kerikilan.
\end{abstract}

Kata Kunci : granulometry, parameter statistik sedimen, nomenklatur, megaskopis, analisis besar butir.

\section{Latar Belakang}

Kabupaten Serdang Bedagai terletak di Provinsi Sumatera Utara memiliki luas wilayah $\pm 1.900,22 \mathrm{~km}^{2}$, dan memiliki pesisir yang cukup panjang, yaitu sekitar $\pm 95 \mathrm{~km}$, dengan garis pantai sepanjang $\pm 51 \mathrm{~km}$ yang mencakup 5 (lima) kecamatan dengan jumlah 23 desa (BPS, 2018)[1]. Perairan Serdang Bedagai memiliki potensi bahan tambang yang sering diperlukan sebagai bahan utama dalam proses reklamasi daerah pesisir. Mengingat potensi yang dimilikinya tersebut, penelitian lebih lanjut terkait karakteristik sedimen di perairan Serdang Bedagai perlu dilakukan. Data tentang jenis sedimen dan sebarannya akan sangat diperlukan untuk memberikan gambaran awal mengenai kondisi di wilayah penambangan.

\section{Metodologi}

A.Lokasi penelitian

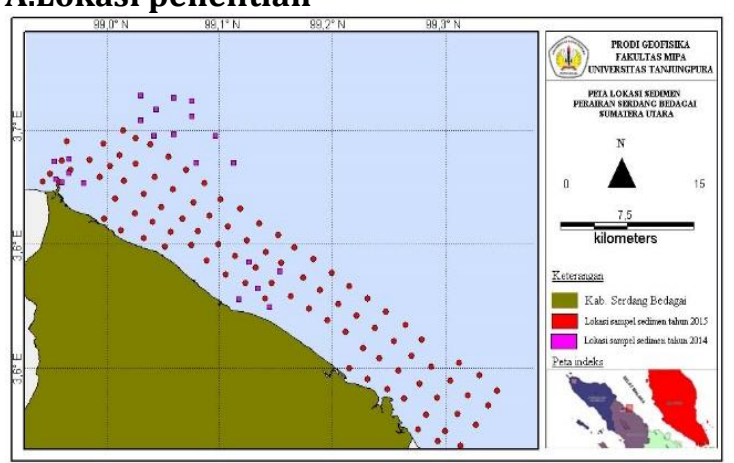

Gambar 1. Lokasi pengambilan sedimen

Penelitian ini dilakukan di perairan Serdang Bedagai Sumatera Utara dengan posisi geografis $02^{\circ} 57^{\prime}-03^{\circ} 16^{\prime}$ LU dan $98^{\circ} 33^{\prime}-99^{\circ} 27^{\prime}$ pada tanggal 14 agustus hingga 21 september 2015 dan tanggal 19 agustus hingga 22 agustus 2014. Perairan serdang Bedagai berhadapan langsung dengan selat malaka sehingga dapat dikatakan sebagai perairan terbuka.

\section{B. Analisis sampel}

Analisis sampel dilakukan menggunakan dua metode yaitu analisis besar butir dan analisis megaskopis sedimen. Analisis besar butir sedimen dilakukan dengan proses pengayakan kering (granulometry) dengan berat masingmasing sampel 100 gram untuk fraksi sedimen yang berdiameter $4 \mathrm{~mm}$ - 0,063 mm (fraksi kerikil hingga pasir) serta sekitar 20 gram untuk fraksi sedimen yang memiliki diameter 0,063 $\mathrm{mm}$ - 0,004 mm (fraksi lumpur) dan sedimen yang tersisa di pan. Pengayakan dilakukan menggunakan standar mesh American Society and Testing Material (ASTM) dengan interval kelas set ayakan 0,5 phi.

Analisis megaskopis bertujuan untuk mendeskripsikan karakter fisik sedimen seperti warna, tekstur, bentuk, dan jenis kebundaran. Dilakukan menggunakan lup geologi dengan perbesaran 10 kali dan komparator butir sedimen yang digunakan untuk mendskripsikan sedimen yang diamati;

\section{Nomenklatur sedimen}

Nomenklatur sedimen dilakukan menggunakan segitiga folk (1980) ${ }^{[2]}$ yang terbagi menjadi 2 kelas dimana kelas pertama (gambar 2(a)) digunakan untuk sedimen yang 
mengandung kerikil. Segitiga folk pada kelas ini didasarkan pada proporsi persentase kerikil terhadap perbandingan lumpur dan pasir. Kelas kedua (gambar 2 (b)) digunakan untuk sedimen tanpa kerikil dan didasarkan pada proporsi persentase pasir terhadap perbandingan lanau dan lempung.

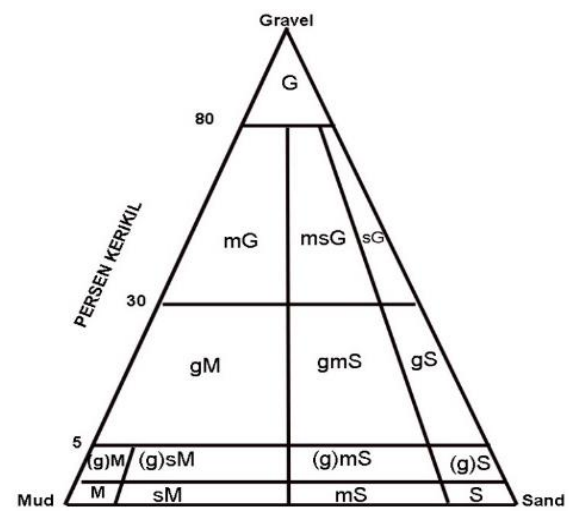

(a)

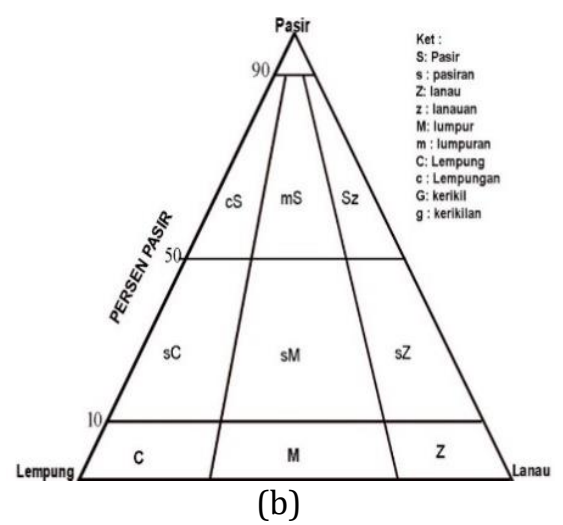

Gambar 2. Nomenklatur butiran sedimen (Folk,1980).

\section{Parameter statistik sedimen}

Penentuan nilai statistik sedimen dilakukan menggunakan 4 parameter yaitu mean yang merupakan nilai rata-rata ukuran butiran, sortasi yang merupakan nilai standar deviasi ukuran butir yang menunjukkan tingkat keseragaman, Skewness yang merupakan penyimpangan distribusi ukuran butir terhadap distribusi normal dan kurtosis yang merupakan derajat keruncingan suatu distribusi yang mengacu pada bentuk kurva distribusi normal, tinggi rendah atau runcing datar nya puncak dari suatu kurva. Perhitungan nilai statistik sedimen dilakukan mengggunakan metode momen logaritmik dengan persamaan sebagai berikut :

1. $\operatorname{Mean}\left(\bar{X}_{\varnothing}\right)$

$$
\bar{X}_{\varnothing}=\frac{\Sigma f m_{\varnothing}}{100}
$$

2. Sorting $\left(\sigma_{\varnothing}\right)$

$$
\sigma_{\varnothing}=\sqrt{\frac{\Sigma f\left(f m_{\varnothing}-\bar{X}_{\varnothing}\right)^{2}}{100}}
$$

3. Skewness (Skø)

$$
S k_{\varnothing}=\frac{\Sigma f\left(f m_{\varnothing}-\bar{X}_{ø}\right)^{3}}{100 \sigma_{\varnothing}{ }^{3}}
$$

4. Kurtosis $(k ø)$

$$
\left(k_{\varnothing}\right)=\frac{\sum f\left(f m_{\varnothing}-\bar{X}_{\varnothing}\right)^{4}}{100 \sigma_{\varnothing^{4}}}
$$

Dimana $f$ merupakan frekuensi berat (\%) pada setiap fraksi dan $m_{\varnothing}$ adalah nilai tengah dari setiap ukuran kelas. Selanjutnya nilai Mean, skewness, kurtosis, dan sorting diklasifikasikan berdasarkan rentang nilai yang terdapat pada tabel 1, tabel 2 dan tabel 3.

Pada skala phi diameter butir dinyatakan sebagai :

$$
\emptyset=-3,3219 \log 10(D)
$$

Dimana D merupakan diameter butir dalam mm. Sedangkan untuk konversi dari phi ke unit mm digunakan persamaan:

$$
\mathrm{D}=2^{-\varnothing}
$$

Tabel 1 Klasifikasi derajat sorting $\left(\sigma_{\varnothing}\right)$

\begin{tabular}{l} 
Nilai Sorting $(\varnothing)$ \\
\hline$<0,25$ \\
0,35 sampai 0,25 \\
0,50 sampai 0,71 \\
\\
0,71 sampai 1,0 \\
1,0 sampai 2,0 \\
2,0 sampai 4,0 \\
$>4,0$
\end{tabular}
Klasifikasi Very well sorted well sorted Moderately well sorted Moderately sorted Poorly sorted Very Poorly sorted Extremely Poorly sorted

(Sumber : Bloth dan pye,2001) ${ }^{[3]}$

Tabel 2. klasifikasi derajat Skewness Nilai Skewness (ø) Klasifikasi

\begin{tabular}{ll}
\hline$>1.30$ & Very fine skewed \\
0,43 sampai 1,30 & Fine skewed \\
-0,43 sampai 0,43 & Simetrically \\
$-0,43$ sampai $-1,30$ & $\begin{array}{l}\text { Coarse skewed } \\
\text { Very coarse } \\
\text { skewed }\end{array}$ \\
\hline
\end{tabular}

(Sumber : Bloth dan Pye,2001)

Tabel 3. klasifikasi derajat kurtosis

\begin{tabular}{ll}
\hline Nilai kurtosis $(\varnothing)$ & \multicolumn{1}{c}{ Klasifikasi } \\
\hline$<1.70$ & Very platykurtic \\
0,70 sampai 2,55 & Platykurtic \\
2,55 sampai 3,70 & Mesokurtic \\
3,70 sampai 7,40 & Leptokurtic \\
$>$ 7,40 & Veryleptokurtic \\
\hline
\end{tabular}

(Sumber : Bloth dan Pye,2001) 


\section{Hasil dan pembahasan}

\section{A. Analisis statistik butiran sedimen}

Berdasarkan hasil penelitian diketahui bahwa nilai rata-rata ukuran butir sedimen di Perairan Serdang Bedagai memiliki nilai $\varnothing \quad 0,3$ sampai dengan 5,6. Terdiri dari 2 fraksi utama yaitu pasir dengan nilai $\varnothing$ berkisar 0,3 hingga 4 dan lanau dengan nilai $\varnothing$ berkisar 4,1 hingga 5,6. Selanjutnya, fraksi pasir dan lanau tersebut terbagi ke dalam beberapa kelompok. Sedimen dengan fraksi pasir terdiri dari pasir kasar, sedang dan halus. Sedangkan untuk fraksi lanau terdiri dari lanau kasar dan sedang. Menurut Rifardi (2012) ${ }^{[4]}$ nilai rata-rata pada ukuran butir sedimen dapat menggambarkan distribusi pengendapan yang terjadi diwilayah tersebut. Distribusi pengendapan itu sendiri disebabkan oleh beberapa faktor seperti perbedaan ukuran material induk dan kemampuan aliran yang dapat mempengaruhi proses terjadinya sedimen. Sortasi (pemilahan) merupakan nilai standar deviasi yang dapat menunjukkan tingkat keragaman ukuran butir dan merupakan perwujudan matematis dari standar deviasi. Nilai sortasi dapat mengindikasikan lingkupan energi yang dapat mempengaruhi distribusi ukuran butiran sedimen di suatu lokasi hasil klasifikasi nilai pemilahan pada lokasi penelitian didominasi oleh terpilah buruk dengan nilai $\varnothing$ berkisar 1 sampai dengan 2. Dari hasil tersebut dapat disimpulkan bahwa jenis sedimen pada lokasi penelitian berada dalam keadaan yang kurang terpilah karena memiliki perbedaan ukuran butir yang besar. Tingginya nilai pemilahan pada ukuran butir sedimen mengindikasikan adanya pengangkutan sedimen yang terjadi pada level energi yang bervariasi atau kurang stabil. Variasi energi tersebut mendorong terjadinya variasi pada ukuran butir yang dapat terdeposisi sehingga mengakibatkan ukuran butir terendapkan secara acak yang dikarenakan oleh pengaruh fluktuasi kuat arus pembawa.

Kurtosis mengukur puncak dari kurva dan berhubungan dengan penyebaran distribusi normal. Berdasarkan hasil penelitian diketahui bahwa perairan serdang bedagai bahwa nilai kurtosis sedimen pada lokasi penelitian didominasi oleh nilai $\emptyset 2,6$ hingga 3,7. Nilai-nilai tersebut mengindikasikan bahwa lokasi penelitian memiliki sebaran sedimen yang normal dan pemilahan yang buruk.
Skewness menunjukkan nilai kesimetrisan dan penyimpangan distribusi ukuran butir terhadap distribusi normal. Nilai skewness mencirikan arah dominan ukuran butir pada suatu populasi sedimen. Hasil penelitian menunjukkan bahwa sedimen pada perairan Serdang Bedagai didominasi oleh kategori simetris dengan nilai $\emptyset$ yang berkisar antara -0,3 hingga -0,4. Kategori simetris mencirikan bahwa sedimen pada lokasi penelitian memiliki ukuran butir yang bervariasi. hal ini senada dengan hasil yang diperoleh pada nilai sortasi dan kurtosis. . Menurut Rifardi (2008) ukuran butir yang beragam menunjukkan bahwa sedimen tersebut terbentuk karena adanya arus dan gelombang yang tidak stabil dimana pada suatu masa tertentu mengalami arus dan gelombang yang kuat sedangkan pada masa yang lain mengalami kuat arus dan gelombang yang lemah.

\section{B. Megaskopis sedimen}

Analisis megaskopis merupakan analisis yang meliputi perincian beberapa sifat pokok sedimen yang dapat diukur berdasarkan atas penerimaan indera kita seperti bentuk,warna dan tekstur sedimen. Berdasarkan hasil analisis megaskopis diketahui bahwa karakteristik sedimen di perairan Serdang Bedagai didominasi oleh pasir, warna coklat gelap dan coklat terang dengan bentuk butir membundar, memiliki besar butir pasir sedang, dan struktur sedimen non klastika dimana butiran umumnya berasosiasi dengan fragmen terumbu karang dan fragmen cangkang. Hal ini menunjukkan bahwa sedimen tersebut terbentuk oleh pengendapan material ditempat tersebut (insitu) secara organik yang disebabkan oleh aktivitas makhluk hidup seperti binatang atau tumbuh-tumbuhan misalnya binatang laut (karang), terkumpulnya cangkang binatang (fosil) atau terkuburnya kayu-kayuan sebagai akibat penurunan daratan menjadi laut.

\section{Jenis dan sebaran sedimen}

Berdasarkan hasil nomenklatur sedimen menggunakan segitiga folk yang diperlihatkan pada gambar 1 diketahui bahwa di perairan Serdang Bedagai terdiri atas pasir, pasir lanauan, lanau pasiran, lanau, pasir sedikit kerikilan, dan pasir lumpuran sedikit kerikilan. Dari gambar tersebut terlihat bahwa pasir sedikit kerikilan mendominasi dibandingkan jenis yang lainnya dan memiliki persentase sebesar 36,84\%. 

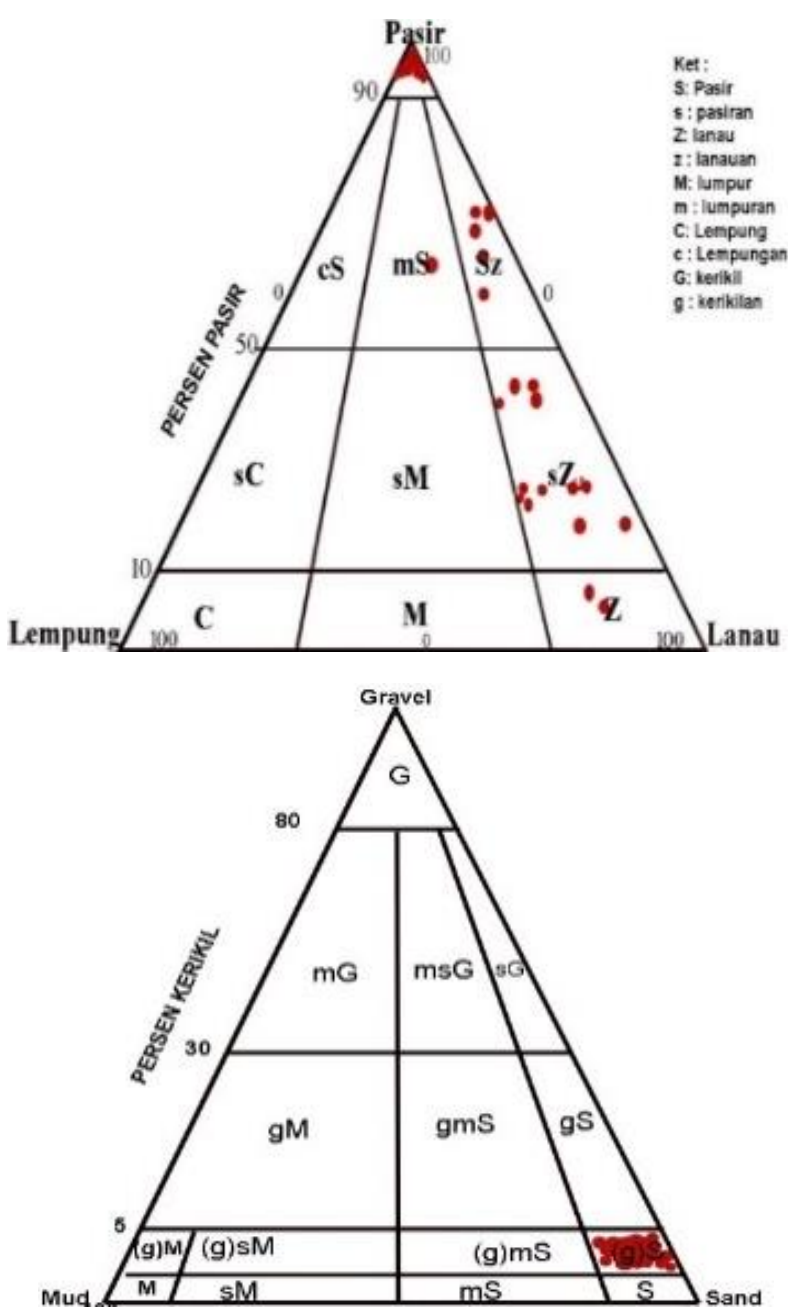

Gambar 3. Hasil nomenklatur sedimen
Gambar 3 memperlihatkan hasil sebaran sedimen. Dari gambar tersebut diketahui bahwa sebaran sedimen secara keseluruhan didominasi oleh pasir sedikit kerikilan dimana secara tekstur satuan ini memiliki persentase pasir 95,2\% sampai dengan 99,9\% dan persentase kerikil 0,1 \% sampai dengan 4,8\%. Distribusi sedimen di sepanjang garis pesisir pantai dari arah tenggara hingga barat laut didominasi oleh pasir dan lanau pasiran. Perbedaan modus disepanjang garis pantai menggambarkan partikel sejajar pantai mengalami perubahan ukuran butir dari pasir hingga lanau. Adanya perbedaan ukuran butir sedimen dari halus hingga kasar (lanau-kerikil) seperti yang diperlihatkan oleh gambar 2 mengindikasikan bahwa pola transportasi pada perairan Serdang Bedagai terdiri dari transportasi bedload dan suspensi. dimana sedimen akan terangkut cukup jauh dalam suatu aliran hingga akhirnya sedimen tersebut mengendap pada daerah yang memiliki kecepatan arus yang rendah. Menurut Nugroho dan Basir (2014) ${ }^{[5]}$ terdapatnya sedimen berukuran kasar pada suatu perairan menunjukkan bahwa perairan tersebut memiliki arus dan gelombang yang relatif kuat.dan pada umumnya diendapkan pada perairan terbuka yang berhubungan langsung dengan laut lepas. Sedangkan sedimen halus diendapkan pada daerah dengan arus yang benar-benar tenang.

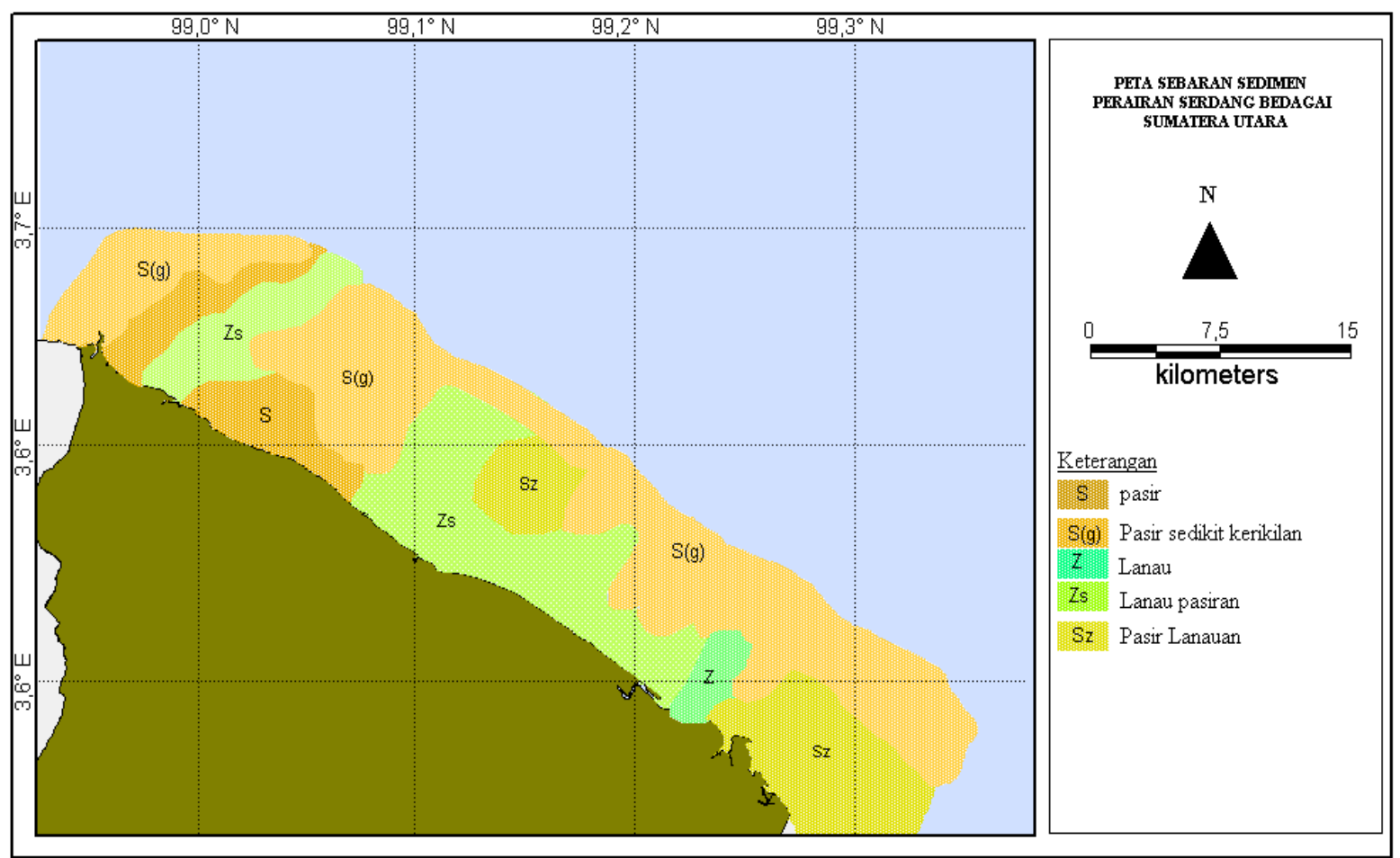

Gambar 4. Peta sebaran sedimen 


\section{Kesimpulan}

Dari penelitian yang telah dilakukan dapat disimpulkan bahwa berdasarkan analisis statistik sedimen diketahui bahwa sedimen di Perairan Serdang Bedagai memiliki nilai ratarata dengan nilai $\varnothing$ sebesar 0,3 sampai dengan 5.6 dan terdiri dari 2 (dua) jenis fraksi utama yaitu pasir dan lanau. Klasifikasi butiran sedimen didominasi oleh kelas terpilah baik, simetris untuk skewness dan sedang untuk nilai kurtosis. Hasil analisis megaskopis menunjukka bahwa karakter fisik sedimen di Perairan Serdang Bedagai memiliki warna coklat, bentuk butir membundar, struktur yang homogen dan komposisi non klastika.

Sedimen yang tersebar di Perairan Serdang Bedagai terdiri dari fraksi kasar hingga halus yaitu kerikil, pasir, lanau dan lempung. Berdasarkan hasil nomenklatur sedimen menggunakan segitiga folk (1980) diketahui bahwa dasar Perairan Serdang Bedagai ditutupi oleh 5 jenis sedimen yaitu pasir, pasir lanauan, pasir sedikit kerikilan, lanau dan lanau pasiran dan didominasi oleh pasir kerikilan dengan persentase $36,84 \%$.

\section{Pengakuan}

Terima kasih kepada bapak Yudha Arman D.Sc yang telah bersedia membimbing selama proses penelitian sampai dapat diterbitkannya jurnalini.

\section{Daftar pustaka}

[1] Badan Pusat Statistik Serdang Bedagai, Statistik daerah kabupaten Serdang Bedagai 2018,BPS kabupaten Serdang Bedagai,2018.

[2] Folk, L .R., Petrology of sedimentary rocks, Hemphill publishing company, Austin, 170 pages,1980.

[3] Blot, J. S. And Pye, K., Gradistat: a grain size distribution and statistics package for the analysis of unconsolidated sediments, $j$. Earth surface processes landforms.,26: 12371248, 2001.

[4] Rifardi., Tekstur sedimen sampling dan analisis, Pekanbaru, Unri Press Pekanbaru, 2008.
[5] Nugroho, H. S. Dan Basit, A., Sebaran sedimen berdasarkan analisis ukuran butir di Teluk Weda Maluku Utara, j. Ilmu kelautan dan teknologi tropis., 6: 229-240, 2014. 